\title{
RANCANG BANGUN SIMULATOR SISTEM INTERLOCK PADA IRADIATOR MERAH PUTIH BERBASIS LABVIEW
}

\author{
Adib Afham, Muhtadan', Achmad Suntoro² \\ 1) STTN-BATAN, Kawasan BATAN Yogyakarta, Depok, Sleman, Yogyakarta, \\ adibsttn@gmail.com,muhtadan@batan.go.id \\ 2) PRFN-BATAN, Kawasan Puspiptek, Gedung 71, Lt. 2, Serpong, Tangerang Selatan, \\ Banten, suntoro@batan.go.id
}

\begin{abstract}
ABSTRAK
RANCANG BANGUN SIMULATOR SISTEM INTERLOCK PADA IRADIATOR MERAH PUTIH BERBASIS LABVIEW. Sistem interlock merupakan suatu fasilitas pengaman untuk mewujudkan aspek keselamatan pada iradiator merah putih (IMP). Sebuah simulator yang dapat merepresentasikan cara kerja dari sistem interlock IMP dibutuhkan untuk mempelajari sistem interlock IMP. Diharapkan simulator sistem interlock dapat menjadi sebuah media pembelajaran, penunjang, dan pelatihan bagi mahasiswa maupun calon operator iradiator dalam mempelajari sistem interlock IMP.

Sistem interlock IMP memiliki 2 kategori kegagalan, yaitu kategori A dan kategori B serta memiliki 17 tipe deteksi kegagalan. Terdapat 3 kondisi operasi yang mungkin terjadi saat proses operasi IMP, yaitu kondisi normal, kondisi terjadi gangguan saat sumber masih di dasar kolam penyimpanan, dan kondisi terjadi gangguan saat sumber telah diangkat naik dari dasar kolam penyimpanan. Simulator dibuat dengan menggunakan perangkat lunak LabVIEW.

Simulator yang dibangun telah dapat merepresentasikan sistem kerja interlock IMP yang sebenarnya. Waktu yang dibutuhkan untuk mengangkat sumber iradiasi dari dasar kolam penyimpanan hingga sampai ke permukaan kolam penyimpanan adalah 10 detik, begitu pula untuk waktu penurunan sumber dari permukaan kolam hingga ke dasar kolam adalah 10 detik dengan tinggi kolam penyimpanan sumber sedalam 6 meter. Diharapkan simulator mampu memberikan pengertian tentang sistem kerja dari sistem interlock IMP.
\end{abstract}

Kata kunci: IMP, interlock, LabVIEW.

\section{ABSTRACT}

A DESIGN OF INTERLOCK SYSTEM SIMULATOR FOR MERAH PUTIH IRRADIATOR BASED ON LABVIEW. Interlock system is a safety facility to realize the safety aspects of Merah Putih Irradiator (IMP). A simulator that can represent the workings of IMP interlock systems needed to learn IMP interlock systems. It is expected that the interlock system simulator can be a medium of learning, support, and training for students and prospective irradiator operators in learning IMP interlock system.

IMP interlock system has 2 categories of failure, namely category $A$ and category $B$, and has 17 types of failure detection. There are 3 operating conditions that may occur during IMP operation process; normal condition, disturbance condition when source is still at bottom of storage pool, and condition of disturbance when source has lifted up from bottom of storage pool. The simulator has been created by using LabVIEW software.

The simulator has been able to represent the actual IMP interlock working system. Need 10 second to lift up the irradiation source from bottom of storage pool to the surface of storage pool, and need 10 second to move down the source from the surface of storage pool to bottom of storage pool with the high of the storage pool is 6 meters. The simulator is expected to provide understanding of the working system of IMP interlock system.

Key words: IMP, interlock, LabVIEW. 


\section{PENDAHULUAN}

Dewasa ini iradiator gamma sebagai perangkat nuklir untuk sterilisasi bahan atau pengawetan makanan mulai berkembang di dunia $^{[1]}$. Badan Tenaga Nuklir Nasional (BATAN) akan merealisasikan pembangunan iradiator yang berlokasikan di Kawasan Puspiptek, Serpong, Tangerang. Fasilitas ini nantinya akan diberi nama Iradiator Merah Putih (IMP) ${ }^{[2]}$.

Sebagai fasilitas yang menggunakan sumber radiasi, iradiator harus mendapat perlakuan yang sama seperti halnya fasilitas iradiasi lainnya terutama pada aspek keselamatan. Demi mewujudkan aspek keselamatan tersebut, maka dalam sistem iradiator dilengkapi dengan suatu sistem pengaman yaitu sistem interlock.

Interlock merupakan salah satu sistem keselamatan yang diterapkan pada suatu peralatan yang memerlukan perhatian khusus sehubungan dengan sistem operasi untuk memperkecil kesalahan yang mungkin ditimbulkannya ${ }^{[3]}$. Parameter keselamatan dalam sistem interlock secara umum berupa parameter yang dapat dilihat (visible: misalnya lampu), parameter yang dapat didengar (audible: misalnya bel alarm atau voice), parameter fisika dan parameter Iistrik ${ }^{[3]}$.

Pada saat ini belum adanya fasilitas simulasi sistem interlock IMP menjadi masalah tersendiri untuk media pembelajaran ataupun pelatihan tentang sistem interlock IMP. Sebagai bentuk media pembelajaran dan pelatihan serta untuk membantu operator dalam operasi iradiator maupun petugas maintenance dalam melakukan proses perbaikan jika ada kegagalan sistem yang mengakibatkan aktifnya sistem interlock IMP, maka dibentuklah simulator untuk sistem interlock IMP.

\section{DASAR TEORI}

\section{Iradiator Merah Putih}

Fasilitas Iradiator gamma Merah Putih (IMP) terletak di Kawasan Puspiptek, Serpong, Tangerang Selatan. Fasilitas ini dibangun sejak tahun 2014. Fasilitas ini menggunakan sumber iradiasi cobalt 60 (Co-60) dengan aktivitas 300 kilocurrie $(\mathrm{kCi})$ sebagai fasilitas utama iradiator yang didatangkan langsung dari Rusia. Fasilitas ini dapat dimanfaatkan untuk pengawetan bahan makanan, bahan obat serta sterilisasi alat kesehatan $^{[4]}$. IMP termasuk ke dalam tipe iradiator kategori IV dimana sumber radiasi akan sepenuhnya tersimpan dan terlindungi di dalam kolam air saat tidak digunakan. Saat dilakukan penyinaran, sumber akan dibawa keluar dari kolam air dan masuk ke dalam ruangan radiasi yang terjaga dan tidak dapat diakses masuk selama beroperasi ${ }^{[5]}$. Skema struktur bangunan dari fasilitas IMP dapat dilihat pada Gambar. 1.

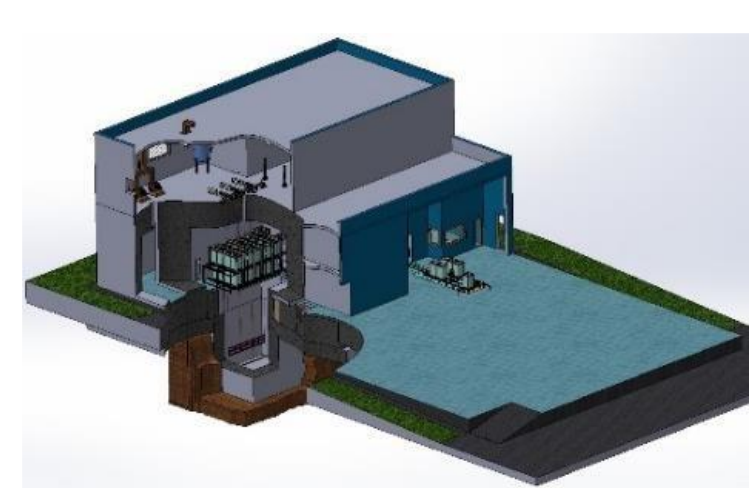

Gambar. 1. Struktur bangunan fasilitas IMP

\section{Sistem Interlock}

Sistem interlock merupakan salah satu sistem keselamatan yang diterapkan pada suatu peralatan yang memerlukan perhatian khusus sehubungan dengan sistem operasi untuk memperkecil kesalahan yang mungkin ditimbulkannya [3]. Sistem interlock adalah kondisi saling kunci dari beberapa parameter operasi untuk melakukan suatu operasi, suatu operasi tidak dapat beroperasi jika ada salah satu parameter operasi tidak bekerja sebagaimana mestinya ${ }^{[6]}$.

\section{METODE PENELITIAN}

\section{Kategori Deteksi Gangguan}

Sistem interlock IMP bekerja berdasarkan beberapa parameter gangguan yang telah ditetapkan. Parameter-parameter tersebut dimasukkan kedalam kategori-kategori sesuai dengan jenis dan prioritas penanganan akibat dari gangguan tersebut. Pembagian kategori gangguan dapat dilihat pada Tabel. 1. 
Tabel. 1. Pengelompokkan parameter untuk kategori gangguan

\begin{tabular}{|c|c|}
\hline Kategori-A & Kategori-B \\
\hline $\begin{array}{l}\text { Deteksi pintu masuk tote (DPT). } \\
\text { Deteksi penyelinap (intruder) ke } \\
\text { ruang iradiasi (DP). } \\
\text { Deteksi radiasi lingkungan (DRL). } \\
\text { Deteksi kebakaran (DK). } \\
\text { Deteksi ceilling hatch (DCH). } \\
\text { Deteksi status saklar gawat- } \\
\text { darurat (DSG). } \\
\text { Deteksi gempa bumi (DGB). } \\
\text { Deteksi kemacetan carrier di } \\
\text { ruang iradiasi (DKC). } \\
\text { Deteksi ventilasi ruang iradiasi } \\
\text { (DV). } \\
\text { Deteksi suhu sekitar sumber } \\
\text { (DSS). } \\
\text { Deteksi udara tekan (DUT). } \\
\text { Deteksi level air kolam } \\
\text { penyimpanan sumber radiasi } \\
\text { (DL). }\end{array}$ & $\begin{array}{l}\text { Deteksi catu daya listrik } \\
\text { (DCL). } \\
\text { Deteksi gas ozon (DGO). } \\
\text { Deteksi sistem } \\
\text { pengamanan gedung } \\
\text { (DSP). } \\
\text { Deteksi konduktifitas air } \\
\text { kolam penyimpanan } \\
\text { sumber radiasi (DKA). } \\
\text { Deteksi sirkulasi air } \\
\text { kolam (DSA). }\end{array}$ \\
\hline
\end{tabular}

Secara keseluruhan parameter deteksi kegagalan yang digunakan berjumlah 17 parameter. Ada beberapa data dari parameter deteksi kegagalan tertentu didapat dari beberapa sensor deteksi kegagalan. Sensor-sensor untuk Deteksi Penyelinap (intruder) ke ruang iradiasi berjumlah 5 buah yang diberi nama $\mathrm{P} 1$ sampai P 5, sensor-sensor untuk Deteksi Radiasi Lingkungan berjumlah 6 buah dan diberi nama R 1 sampai R 6, sensor-sensor untuk Deteksi Status Gawat Darurat berjumlah 6 buah dan diberi nama SE 1 sampai SE 6, serta sensorsensor untuk Deteksi Kebakaran berjumlah 28 buah dan diberi nama K 1 sampai K 28.

\section{Aturan Umum Sistem Interlock IMP}

Dalam melakukan operasi IMP, langkah awal yang perlu dilakukan adalah mengaktifkan semua saklar kunci yang ada (saklar kunci di ruang iradiasi dan saklar kunci di ruang kendali), jika kunci saklar tidak diaktifkan maka iradiator tidak akan dapat beroperasi dan sumber tidak dapat diangkat naik dan jika saklar kunci di non-aktifkan pada saat sumber sedang berada diatas atau dalam posisi operasi maka sumber akan langsung diturunkan ke dalam kolam penyimpanan. Pada saat sumber berada dibawah serta tidak terdeteksi adanya gangguan pada kategori kegagalan manapun maka sumber akan dapat diangkat naik ke permukaan untuk melakukan proses iradiasi yang dilakukan berdasarkan langkah berikut ini :

1. Tekan tombol siap.

2. Tekan tombol naik.
3. Akan ada bunyi alarm sebelum sumber diangkat naik selama 10 detik. Sumber masih berada dibawah pada saat ini.

4. Sumber akan terangkat naik dan alarm akan tetap hidup sampai sumber berada di atas permukaan atau pada posisi operasi iradiasi. Waktu yang diperlukan sumber untuk naik dari dasar kolam hingga sampai ke permukaan kolam penyimpanan adalah 10 detik.

5. Pada saat menurunkan sumber radiasi dilakukan dengan cara menekan tombol siap dan lalu menekan tombol turun. Waktu yang diperlukan sumber untuk turun dari permukaan kolam hingga sampai ke dasar kolam penyimpanan adalah 10 detik.

6. Jika tombol naik dan tombol turun ditekan bersamaan secara disengaja maupun tidak maka yang didahulukan adalah perintah dari tombol turun.

Pada saat sumber berada dibawah serta terdeteksi terjadi salah satu gangguan pada kategori kegagalan manapun maka sumber tidak akan dapat diangkat naik ke permukaan untuk melakukan proses iradiasi. Akan tetapi ketika sumber sedang digunakan dalam proses iradiasi dan saat itu terdeteksi terjadinya gangguan maka perintah akibat gangguan tersebut dikelompokkan menjadi dua kategori perintah, yaitu sebagai berikut :

1. Nyalakan alarm dan turunkan langsung sumber radiasi ke kolam penyimpanan sumber (Kategori A).

2. Nyalakan alarm dan pengendalian diserahkan kepada operator secara manual untuk menurunkan atau tidak menurunkan sumber radiasi ke kolam penyimpanan sumber (Kategori B).

\section{Aturan Operasi Logika Deteksi Gangguan dan Kunci Iradiasi}

Sistem kerja dari sistem interlock IMP didasarkan dari aturan-aturan operasi logika yang berupa bilangan Boolean (keadaan true (1) atau false (0)) serta operasi gerbang logika AND, OR, NOT, XOR, EX-NOR, NAND, ataupun NOR. Aturan operasi logika deteksi gangguan pada sistem interlock disusun secara logika AND antar setiap deteksi gangguan terhadap kategori gangguannya. Sensor deteksi akan memberikan kondisi true (1) jika tidak 
terjadi gangguan dan akan memberikan kondisi false (0) jika terdeteksi terjadinya gangguan.

Tabel kebenaran hubungan antara sensor deteksi dengan deteksi gangguannya terlihat pada Tabel. 2 untuk deteksi penyelinap (intruder) ke ruang iradiasi, Tabel. 3 untuk deteksi radiasi lingkungan, Tabel. 4 untuk deteksi status saklar gawat-darurat, dan Tabel.L1 untuk deteksi kebakaran.

Tabel. 2. Tabel logika hubungan antar sensor deteksi penyelinap (intruder) ke ruang iradiasi

\begin{tabular}{cccccc}
\hline \multicolumn{7}{c}{ Nama sensor } & DP \\
\hline P 1 & P 2 & P 3 & P 4 & P 5 & \\
\hline 0 & X & X & X & X & 0 \\
X & 0 & X & X & X & 0 \\
X & X & 0 & X & X & 0 \\
X & X & X & 0 & X & 0 \\
X & X & X & X & 0 & 0 \\
1 & 1 & 1 & 1 & 1 & 1 \\
\hline
\end{tabular}

Tabel. 3. Tabel logika hubungan antar sensor deteksi radiasi lingkungan

\begin{tabular}{|c|c|c|c|c|c|c|}
\hline \multicolumn{6}{|c|}{ Nama sensor } & \multirow{2}{*}{ DRL } \\
\hline$R 1$ & $R 2$ & $R 3$ & $R 4$ & $R 5$ & $R 6$ & \\
\hline 0 & $x$ & $X$ & $x$ & $X$ & $x$ & 0 \\
\hline$x$ & 0 & $x$ & $x$ & $x$ & $x$ & 0 \\
\hline$x$ & $x$ & 0 & $x$ & $x$ & $x$ & 0 \\
\hline$x$ & $x$ & $x$ & 0 & $x$ & $x$ & 0 \\
\hline$x$ & $x$ & $x$ & $x$ & 0 & $x$ & 0 \\
\hline$x$ & $x$ & $x$ & $x$ & $x$ & 0 & 0 \\
\hline 1 & 1 & 1 & 1 & 1 & 1 & 1 \\
\hline
\end{tabular}

Tabel. 4. Tabel logika hubungan antar sensor deteksi status saklar gawat-darurat

\begin{tabular}{|c|c|c|c|c|c|c|}
\hline \multicolumn{6}{|c|}{ Nama sensor } & \multirow{2}{*}{ DSG } \\
\hline SE 1 & SE 2 & SE 3 & SE 4 & SE 5 & SE 6 & \\
\hline 0 & $x$ & $x$ & $x$ & $x$ & $x$ & 0 \\
\hline$x$ & 0 & $x$ & $x$ & $x$ & $x$ & 0 \\
\hline$x$ & $x$ & 0 & $x$ & $x$ & $x$ & 0 \\
\hline$x$ & $x$ & $x$ & 0 & $x$ & $x$ & 0 \\
\hline$x$ & $x$ & $x$ & $x$ & 0 & $x$ & 0 \\
\hline$x$ & $x$ & $x$ & $x$ & $x$ & 0 & 0 \\
\hline 1 & 1 & 1 & 1 & 1 & 1 & 1 \\
\hline
\end{tabular}

Deteksi-deteksi gangguan dihubungkan secara operasi logika AND sesuai dengan kategori gangguan. Aturan mengenai operasi logika untuk kategori gangguan terlihat pada Tabel. 5 untuk kategori A dan Tabel. 6 untuk kategori B serta untuk aturan mengenai operasi kunci iradiasi dapat dilihat pada Tabel. 7
Tabel. 5. Operasi logika kategori A

\begin{tabular}{|c|c|c|c|c|c|c|c|c|c|c|c|c|}
\hline \multicolumn{12}{|c|}{ Deteksi kegagalan } & \multirow[b]{2}{*}{ A } \\
\hline$D$ & $D$ & $D$ & $D$ & $D$ & $D$ & $D$ & $D$ & $D$ & $D$ & $D$ & $D$ & \\
\hline $\boldsymbol{P}$ & $P$ & $R$ & c & $s$ & $\boldsymbol{G}$ & $\kappa$ & $\kappa$ & $v$ & $S$ & $U$ & $L$ & \\
\hline$T$ & & $L$ & $H$ & $G$ & B & & $C$ & & $S$ & $T$ & & \\
\hline 0 & $\mathrm{X}$ & $\mathrm{X}$ & $\mathrm{x}$ & $\mathrm{x}$ & $x$ & $x$ & $\mathrm{X}$ & $x$ & $x$ & $\mathrm{x}$ & $x$ & 0 \\
\hline$x$ & 0 & $x$ & $x$ & $x$ & $x$ & $x$ & $x$ & $x$ & $x$ & $\mathrm{x}$ & $x$ & 0 \\
\hline$x$ & $x$ & 0 & $x$ & $x$ & $x$ & $x$ & $x$ & $x$ & $x$ & $\mathrm{x}$ & $x$ & 0 \\
\hline$x$ & $x$ & $x$ & 0 & $x$ & $x$ & $x$ & $x$ & $x$ & $x$ & $\mathrm{x}$ & $\mathrm{x}$ & 0 \\
\hline$x$ & $x$ & $x$ & $x$ & 0 & $x$ & $x$ & $x$ & $x$ & $x$ & $x$ & $x$ & 0 \\
\hline$x$ & $x$ & $x$ & $x$ & $x$ & 0 & $x$ & $x$ & $x$ & $x$ & $x$ & $x$ & 0 \\
\hline$x$ & $x$ & $x$ & $x$ & $x$ & $x$ & 0 & $x$ & $x$ & $x$ & $x$ & $x$ & 0 \\
\hline$x$ & $x$ & $x$ & $x$ & $x$ & $x$ & $x$ & 0 & $x$ & $x$ & $x$ & $x$ & 0 \\
\hline$x$ & $x$ & $x$ & $x$ & $x$ & $x$ & $x$ & $x$ & 0 & $x$ & $x$ & $x$ & 0 \\
\hline$x$ & $x$ & $x$ & $x$ & $x$ & $x$ & $x$ & $x$ & $x$ & 0 & $x$ & $x$ & 0 \\
\hline$x$ & $x$ & $x$ & $x$ & $x$ & $x$ & $x$ & $x$ & $x$ & $x$ & 0 & $x$ & 0 \\
\hline$x$ & $x$ & $x$ & $x$ & $x$ & $x$ & $x$ & $x$ & $x$ & $x$ & $x$ & 0 & 0 \\
\hline 1 & 1 & 1 & 1 & 1 & 1 & 1 & 1 & 1 & 1 & 1 & 1 & 1 \\
\hline
\end{tabular}

Tabel. 6. Operasi logika kategori B

\begin{tabular}{|c|c|c|c|c|c|}
\hline \multicolumn{5}{|c|}{ Deteksi kegagalan } & \multirow{2}{*}{ B } \\
\hline$D S P$ & DKA & DSA & $D C L$ & $D G O$ & \\
\hline 0 & $x$ & $\mathrm{x}$ & $x$ & $x$ & 0 \\
\hline $\mathrm{x}$ & 0 & $x$ & $x$ & $\mathrm{x}$ & 0 \\
\hline$x$ & $x$ & 0 & $x$ & $x$ & 0 \\
\hline $\mathrm{x}$ & $x$ & $\mathrm{x}$ & 0 & $x$ & 0 \\
\hline$x$ & $x$ & $\mathrm{x}$ & $x$ & 0 & 0 \\
\hline 1 & 1 & 1 & 1 & 1 & 1 \\
\hline \multicolumn{2}{|c|}{ Tabel. 7.} & \multicolumn{4}{|c|}{$\begin{array}{l}\text { Operasi logika sistem kunci } \\
\text { IMP }\end{array}$} \\
\hline \multicolumn{3}{|c|}{ Kunci di ruang iradiasi } & \multicolumn{2}{|c|}{ Kunci panel kontrol } & Kunci \\
\hline & 0 & & & 0 & 0 \\
\hline & 0 & & & 1 & 0 \\
\hline & 1 & & & 0 & 0 \\
\hline & 1 & & & 1 & 1 \\
\hline
\end{tabular}

Kondisi X adalah kondisi don't care yang merupakan kondisi bebas baik itu bernilai true (1) atau false (0).

\section{Perancangan Desain}

Desain dari sistem interlock IMP dapat dilihat pada Gambar. 2. Cara kerja dari sitem interlock IMP terbagi menjadi tiga bagian; kondisi normal yang dapat dilihat pada Tabel. 8, kondisi terjadi gangguan saat sumber masih di dasar kolam penyimpanan yang dapat dilihat pada Tabel. 9, dan kondisi terjadi gangguan saat sumber telah diangkat naik dari dasar kolam penyimpanan yang dapat dilihat pada Tabel. 10. 


\section{JURNAL FORUM NUKLIR (JFN) VOLUME 12, NOMOR 1, MEI 2018}

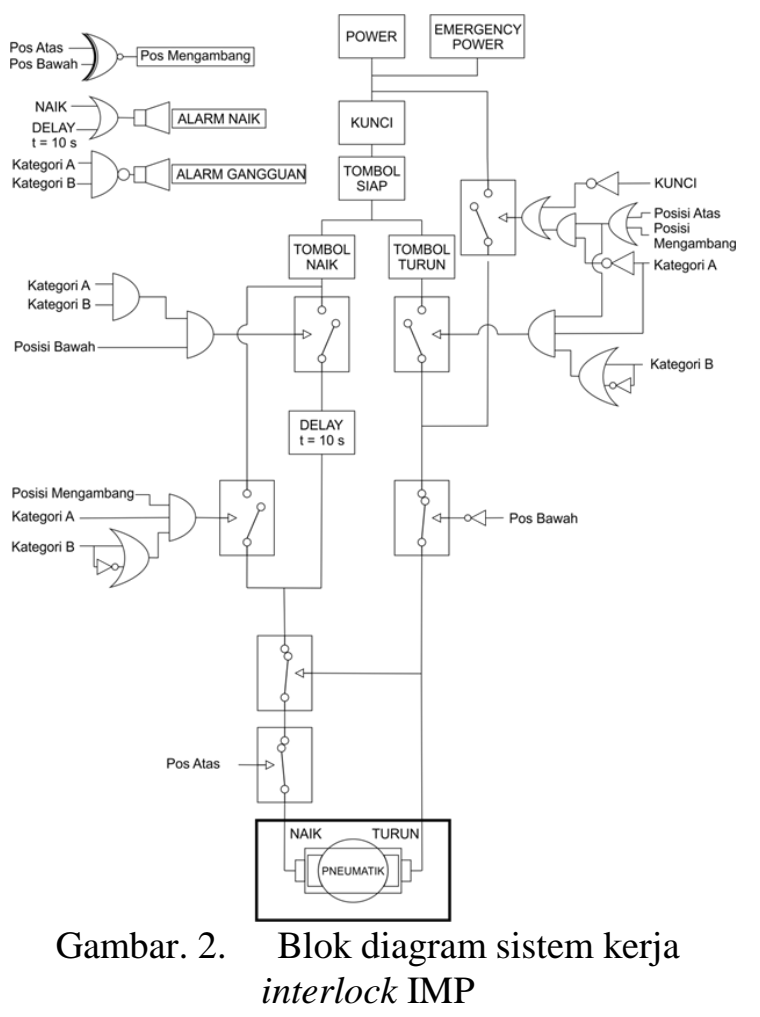

Tabel. 8. Cara kerja interlock pada saat operasi normal

\begin{tabular}{cccccccccc}
\hline PB & PA & SK & TS & TN & TT & N & T & AN & AG \\
\hline 0 & 0 & 0 & X & X & X & 0 & 1 & 0 & 0 \\
0 & 1 & 0 & X & X & X & 0 & 1 & 0 & 0 \\
1 & 0 & 0 & X & X & X & 0 & 0 & 0 & 0 \\
X & $\mathrm{X}$ & $\mathrm{X}$ & 0 & $\mathrm{X}$ & $\mathrm{X}$ & 0 & 0 & 0 & 0 \\
1 & 0 & 1 & 1 & 1 & 0 & 1 & 0 & 1 & 0 \\
$\mathrm{X}$ & 0 & 1 & 1 & 1 & 0 & 1 & 0 & 1 & 0 \\
0 & 1 & 1 & 1 & 1 & 0 & 0 & 0 & 0 & 0 \\
0 & 1 & 1 & 1 & $\mathrm{X}$ & 1 & 0 & 1 & 0 & 0 \\
0 & $\mathrm{X}$ & 1 & 1 & $\mathrm{X}$ & 1 & 0 & 1 & 0 & 0 \\
1 & 0 & 1 & 1 & $\mathrm{X}$ & 1 & 0 & 0 & 0 & 0 \\
\hline
\end{tabular}

Tabel. 9.

Cara kerja interlock saat terjadi gangguan dan sumber masih berada di

\begin{tabular}{cccccccccc}
\multicolumn{10}{c}{ dasar kolam penyimpanan } \\
\hline A & B & SK & TS & TN & TT & N & T & AN & AG \\
\hline 0 & X & X & X & X & X & 0 & 0 & 0 & 1 \\
X & 0 & X & X & X & X & 0 & 0 & 0 & 1 \\
0 & 0 & 0 & X & X & X & 0 & 0 & 0 & 1 \\
0 & 1 & 0 & X & X & X & 0 & 0 & 0 & 1 \\
1 & 0 & 0 & X & X & X & 0 & 0 & 0 & 1 \\
1 & 1 & 0 & X & X & X & 0 & 0 & 0 & 0 \\
0 & 0 & X & 0 & X & X & 0 & 0 & 0 & 1 \\
0 & 1 & X & 0 & X & X & 0 & 0 & 0 & 1 \\
1 & 0 & X & 0 & X & X & 0 & 0 & 0 & 1 \\
1 & 1 & X & 0 & X & X & 0 & 0 & 0 & 0 \\
1 & 1 & 1 & 1 & 1 & 0 & 1 & 0 & 1 & 0 \\
1 & 1 & 1 & 1 & 0 & 1 & 0 & 0 & 0 & 0 \\
1 & 1 & 1 & 1 & 1 & 1 & 0 & 0 & 0 & 0 \\
\hline
\end{tabular}

Tabel. 10. Cara kerja interlock saat terjadi gangguan dan sumber telah diangkat naik dari dasar kolam penyimpanan

\begin{tabular}{|c|c|c|c|c|c|c|c|c|c|c|}
\hline A & B & PA & SK & TS & TN & TT & $\mathbf{N}$ & $\mathbf{T}$ & AN & AG \\
\hline 0 & $x$ & $x$ & $x$ & $x$ & $x$ & $x$ & 0 & 1 & 0 & 1 \\
\hline 0 & 0 & $x$ & 0 & $x$ & $x$ & $x$ & 0 & 1 & 0 & 1 \\
\hline 0 & 1 & $x$ & 0 & $x$ & $x$ & $x$ & 0 & 1 & 0 & 1 \\
\hline 1 & 0 & $x$ & 0 & $x$ & $x$ & $x$ & 0 & 1 & 0 & 1 \\
\hline 1 & 1 & $x$ & 0 & $x$ & $x$ & $x$ & 0 & 1 & 0 & 0 \\
\hline 1 & $x$ & $x$ & 1 & 0 & $x$ & $x$ & 0 & 0 & 0 & $\mathrm{~B}^{-}$ \\
\hline 1 & $x$ & 0 & 1 & 1 & 0 & 0 & 0 & 0 & 0 & $\mathrm{~B}^{-}$ \\
\hline 1 & $x$ & 0 & 1 & 1 & 0 & 1 & 0 & 1 & 0 & $\mathrm{~B}^{-}$ \\
\hline 1 & $x$ & 0 & 1 & 1 & 1 & 0 & 1 & 0 & 1 & $\mathrm{~B}^{-}$ \\
\hline 1 & $x$ & 0 & 1 & 1 & 1 & 1 & 0 & 1 & 0 & $\mathrm{~B}^{-}$ \\
\hline 1 & $x$ & 1 & 1 & 1 & 0 & 0 & 0 & 0 & 0 & $\mathrm{~B}^{-}$ \\
\hline 1 & $x$ & 1 & 1 & 1 & 0 & 1 & 0 & 1 & 0 & $\mathrm{~B}^{-}$ \\
\hline 1 & $x$ & 1 & 1 & 1 & 1 & 0 & 0 & 0 & 0 & $\mathrm{~B}^{-}$ \\
\hline 1 & $x$ & 1 & 1 & 1 & 1 & 1 & 0 & 1 & 0 & $\mathrm{~B}^{-}$ \\
\hline \multicolumn{11}{|c|}{$\begin{array}{l}\text { Keterangan : } \mathrm{A}=\text { Kategori A } \\
\text { B }=\text { Kategori B } \\
\text { PB }=\text { Posisi Bawah } \\
\text { PA }=\text { Posisi Atas } \\
\text { SK }=\text { Saklar Kunci } \\
\text { TS = Tombol Siap } \\
\text { TN = Tombol Naik } \\
\text { TT = Tombol Turun } \\
\text { N }=\text { Naik } \\
\text { T }=\text { Turun } \\
\text { AN }=\text { Alarm Naik } \\
\text { AG }=\text { Alarm deteksi }\end{array}$} \\
\hline
\end{tabular}

\section{Pembuatan Program}

Program utama disusun berdasarkan aturan umum sistem interlock IMP sebagaimana yang telah dijelaskan sebelumnya dan kemudian diimplementasikan kedalam pemrograman LabVIEW. Isi dari program utama dapat dilihat pada Gambar. 3. 


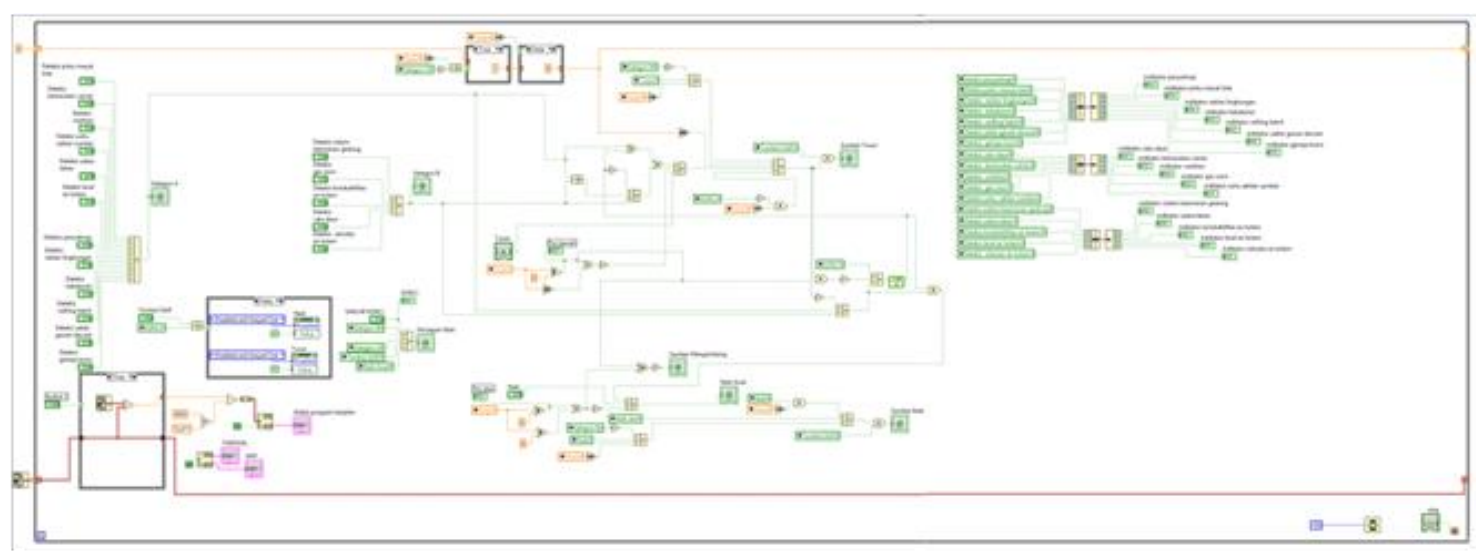

Gambar. 3. Program utama sistem simulator interlock IMP

\section{Perancangan dan Pembuatan Graphical User} Interface (GUI)

Graphical User Interface (GUI) merupakan bentuk antarmuka secara grafis antara pengguna (user) dengan computer. GUI merepresentasikan sistem perangkat lunak yang dibuat agar dapat dimengerti dengan mudah oleh pengguna melalui media grafik sebagai visualisasi. Tampilan GUI dibagi menjadi 4 bagian yaitu tampilan ruang kendali, tampilan yang menunjukkan denah sensor, tampilan untuk petunjuk penggunaan keyboard sebagai media masukkan, dan tampilan petunjuk penggunaan simulator.

\section{HASIL DAN PEMBAHASAN}

\section{Hasil Tampilan GUI}

Setelah program dibuat, GUI disusun sehingga dapat memudahkan pengguna dalam menggunakan perangkat lunak simulator sistem interlock IMP. Hasil tampilan GUI tampilan ruang kendali dapat dilihat pada Gambar. 4, tampilan yang menunjukkan denah sensor dapat dilihat pada Gambar. 5, tampilan untuk petunjuk penggunaan keyboard sebagai media masukkan dapat dilihat pada Gambar. 6, dan tampilan petunjuk penggunaan simulator dapat dilihat pada Gambar. 7.

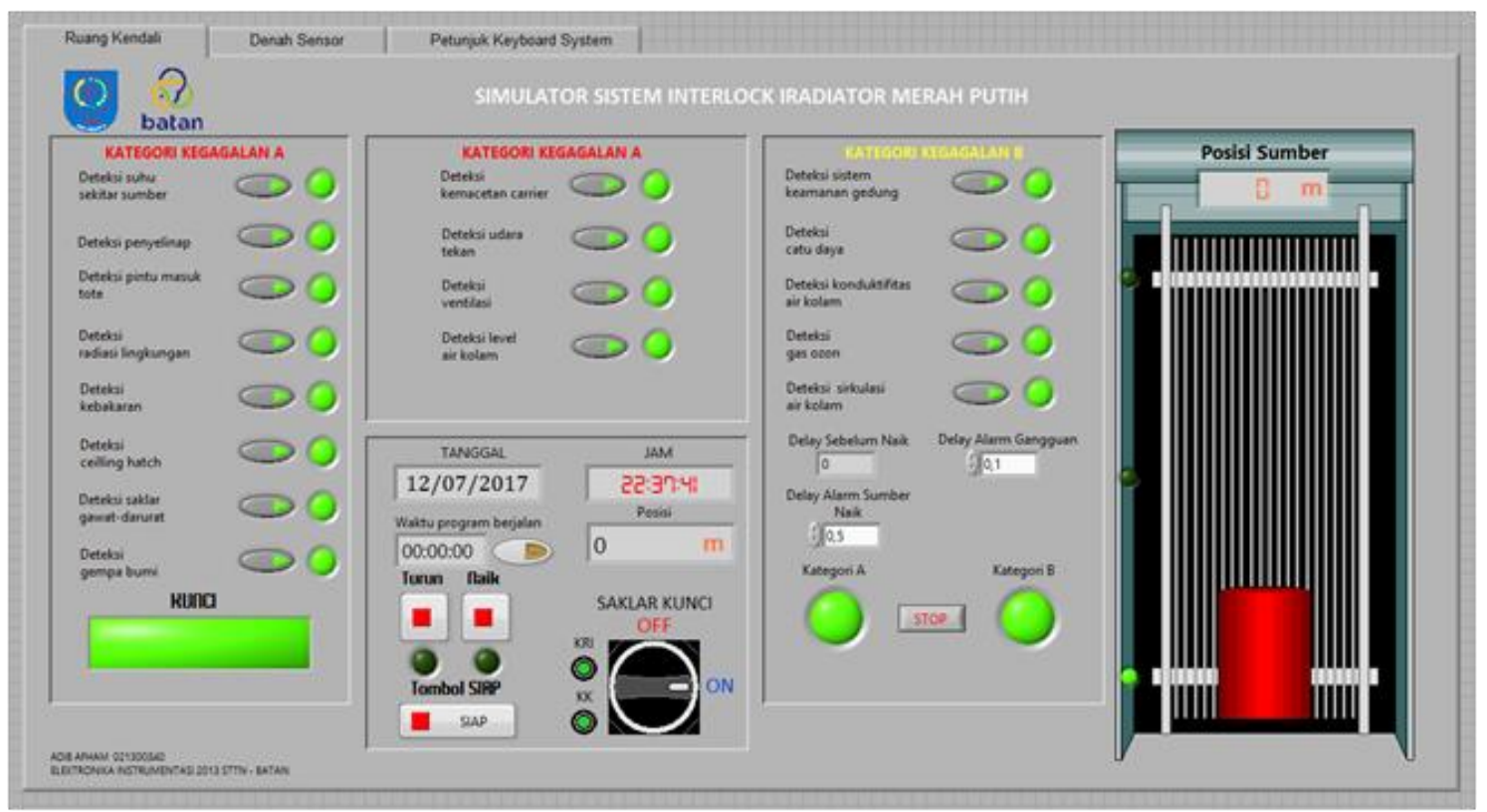

Gambar. 4. Hasil tampilan GUI ruang kendali 


\section{JURNAL FORUM NUKLIR (JFN) VOLUME 12, NOMOR 1, MEI 2018}

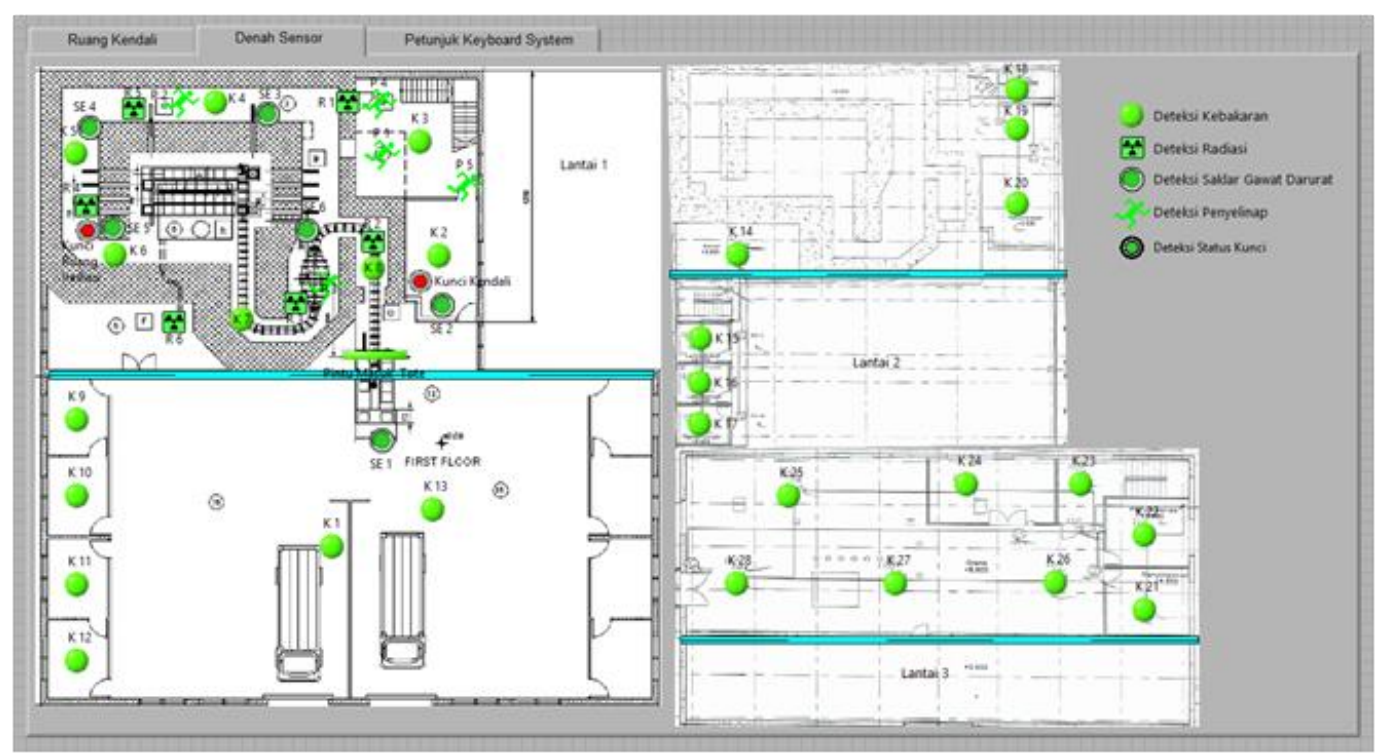

Gambar. 5. Hasil tampilan GUI denah sensor

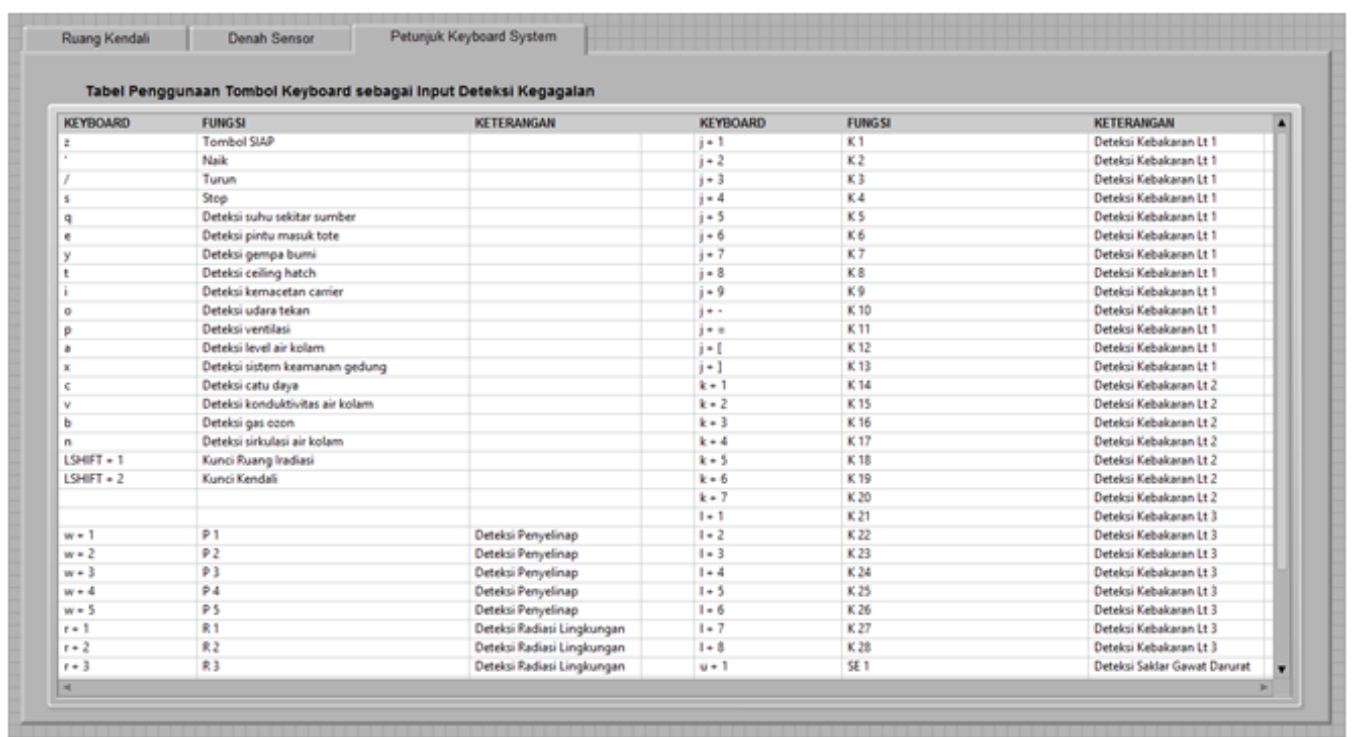

Gambar. 6. Hasil tampilan GUI petunjuk penggunaan keyboard

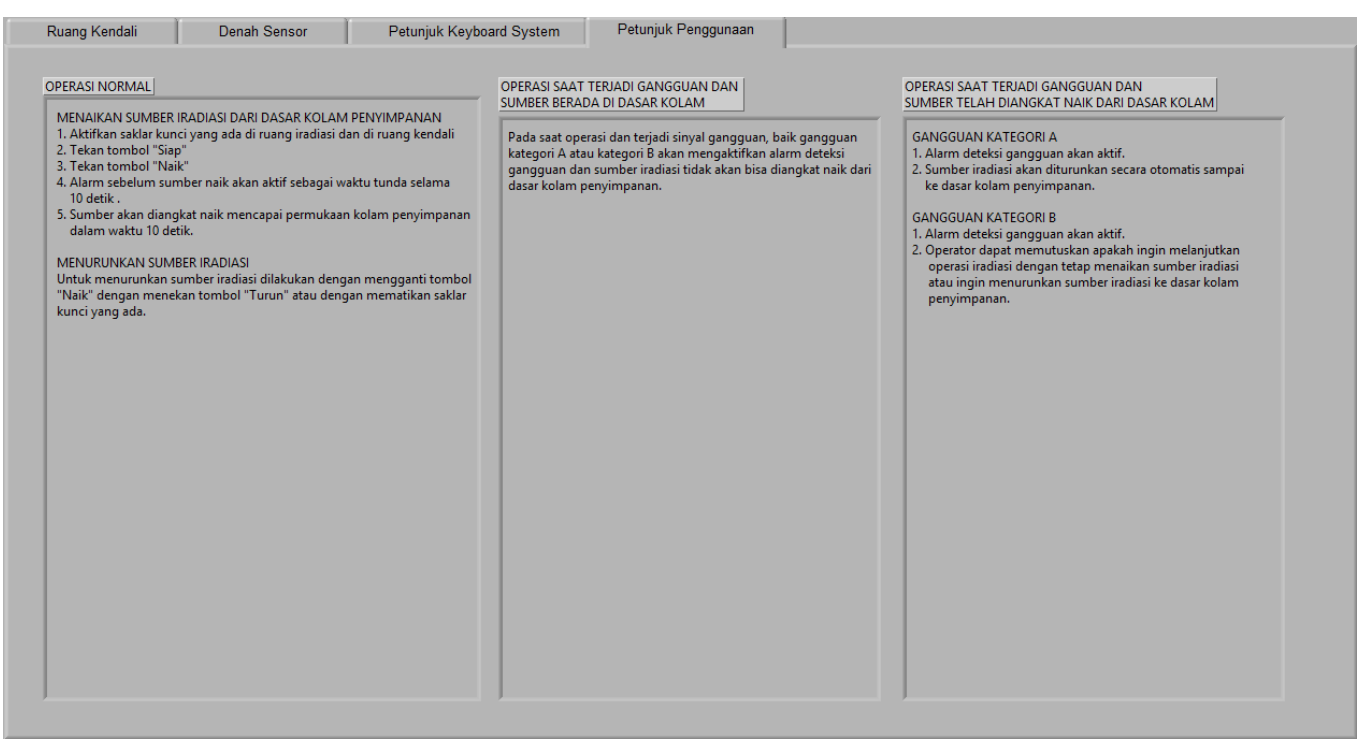

Gambar. 7. Hasil tampilan GUI petunjuk penggunaan simulator 


\section{Hasil Sistem Kerja Simulator Interlock IMP}

Simulator interlock IMP yang dibuat telah sesuai dengan ketentuan-ketentuan sistem kerja dari sistem interlock IMP yang ada. Hasil kerja simulator sistem interlock pada IMP dapat dibuat dalam bentuk tabel logika. Tabel. 11 memberikan informasi hasil pengujian saat operasi normal, 0 memberikan informasi hasil pengujian saat terjadi gangguan dan sumber masih berada di dasar kolam penyimpanan, serta 0 memberikan informasi hasil pengujian saat terjadi gangguan dan sumber telah diangkat naik dari dasar kolam penyimpanan. Dalam pembuktian bahwa simulator telah sesuai dengan sistem kerja sistem interlock IMP sebenarnya dilakukan dengan membandingkan tabel hasil pengujian dengan tabel cara kerja sistem interlock yang terdapat pada Tabel. 8, Tabel. 9, dan Tabel. 10.

Tabel. 11. Hasil pengujian pada saat

\begin{tabular}{cccccccccc}
\multicolumn{10}{c}{ Operasi normal } \\
\hline PB & PA & SK & TS & TN & TT & N & T & AN & AG \\
\hline 0 & 0 & 0 & X & X & X & 0 & 1 & 0 & 0 \\
0 & 1 & 0 & X & X & X & 0 & 1 & 0 & 0 \\
1 & 0 & 0 & X & X & X & 0 & 0 & 0 & 0 \\
X & X & X & 0 & X & X & 0 & 0 & 0 & 0 \\
1 & 0 & 1 & 1 & 1 & 0 & 1 & 0 & 1 & 0 \\
X & 0 & 1 & 1 & 1 & 0 & 1 & 0 & 1 & 0 \\
0 & 1 & 1 & 1 & 1 & 0 & 0 & 0 & 0 & 0 \\
0 & 1 & 1 & 1 & X & 1 & 0 & 1 & 0 & 0 \\
0 & X & 1 & 1 & X & 1 & 0 & 1 & 0 & 0 \\
1 & 0 & 1 & 1 & X & 1 & 0 & 0 & 0 & 0 \\
\hline
\end{tabular}

Tabel. 12. Hasil pengujian saat terjadi gangguan dan sumber masih berada di dasar kolam penyimpanan

\begin{tabular}{cccccccccc}
\hline A & B & SK & TS & TN & TT & N & T & AN & AG \\
\hline 0 & X & X & X & X & X & 0 & 0 & 0 & 1 \\
X & 0 & X & X & X & X & 0 & 0 & 0 & 1 \\
0 & 0 & 0 & X & X & X & 0 & 0 & 0 & 1 \\
0 & 1 & 0 & X & X & X & 0 & 0 & 0 & 1 \\
1 & 0 & 0 & X & X & X & 0 & 0 & 0 & 1 \\
1 & 1 & 0 & X & X & X & 0 & 0 & 0 & 0 \\
0 & 0 & $X$ & 0 & X & X & 0 & 0 & 0 & 1 \\
0 & 1 & $X$ & 0 & X & X & 0 & 0 & 0 & 1 \\
1 & 0 & $X$ & 0 & X & X & 0 & 0 & 0 & 1 \\
1 & 1 & $X$ & 0 & X & X & 0 & 0 & 0 & 0 \\
1 & 1 & 1 & 1 & 1 & 0 & 1 & 0 & 1 & 0 \\
1 & 1 & 1 & 1 & 0 & 1 & 0 & 0 & 0 & 0 \\
1 & 1 & 1 & 1 & 1 & 1 & 0 & 0 & 0 & 0 \\
\hline
\end{tabular}

Tabel. 13. Hasil pengujian saat terjadi gangguan dan sumber telah diangkat naik dari dasar kolam penyimpanan

\begin{tabular}{ccccccccccc}
\hline A & B & PA & SK & TS & TN & TT & N & T & AN & AG \\
\hline 0 & X & X & X & X & X & X & 0 & 1 & 0 & 1 \\
0 & 0 & X & 0 & X & X & X & 0 & 1 & 0 & 1 \\
0 & 1 & X & 0 & X & X & X & 0 & 1 & 0 & 1 \\
1 & 0 & X & 0 & X & X & X & 0 & 1 & 0 & 1 \\
1 & 1 & X & 0 & X & X & X & 0 & 1 & 0 & 0 \\
1 & X & X & 1 & 0 & X & X & 0 & 0 & 0 & B \\
1 & X & 0 & 1 & 1 & 0 & 0 & 0 & 0 & 0 & B \\
1 & X & 0 & 1 & 1 & 0 & 1 & 0 & 1 & 0 & B \\
1 & X & 0 & 1 & 1 & 1 & 0 & 1 & 0 & 1 & B \\
1 & X & 0 & 1 & 1 & 1 & 1 & 0 & 1 & 0 & B \\
1 & X & 1 & 1 & 1 & 0 & 0 & 0 & 0 & 0 & B \\
1 & X & 1 & 1 & 1 & 0 & 1 & 0 & 1 & 0 & B \\
1 & X & 1 & 1 & 1 & 1 & 0 & 0 & 0 & 0 & B \\
1 & X & 1 & 1 & 1 & 1 & 1 & 0 & 1 & 0 & B \\
\hline
\end{tabular}

Dari hasil perbandingan yang telah dilakukan dapat disimpulkan bahwa simulator sistem interlock IMP yang dibuat telah sesuai dengan sistem kerja yang sebenarnya.

\section{KESIMPULAN}

Telah dirancang dan dibuat simulator sistem interlock Iradiator Merah Putih (IMP) yang telah mereperesentasikan sistem kerja dari sistem interlock yang berada di IMP.

Sistem interlock IMP memiliki tiga ketentuan kerja; kondisi operasi normal, kondisi terjadi gangguan saat sumber masih di dasar kolam penyimpanan, dan kondisi terjadi gangguan saat sumber telah diangkat naik dari dasar kolam penyimpanan.

Alarm gangguan akan aktif pada saat terdeteksi gangguan baik itu pada kategori A maupun kategori B dan alarm untuk sumber naik akan aktif pada saat sumber akan diangkat naik serta pada saat sumber diangkat naik ke atas kolam penyimpanan. Waktu yang dibutuhkan sumber iradiasi untuk diangkat naik dari dasar kolam penyimpanan hingga ke permukaan kolam penyimpanan adalah 10 detik, begitu pula sebaliknya.

\section{DAFTAR PUSTAKA}

1. Suntoro Achmad, "Pengendalian PolaGerak Carrier pada Iradiator Gamma ISG500 untuk Hasil Pertanian", Proseding Pertemuan Ilmiah Rekayasa Perangkat Nuklir, pp.189-196, 2011

2. BATAN. (3 February 2017). Indonesia Segera Punya Irradiator Merah Putih. Available: http://www.batan.go.id/index.php/id/kedep 
utian/pendayagunaan-teknologi-

nuklir/rekayasa-fasilitas-nuklir/2020-

indonesia-segera-punya-irradiator-merah-

putih

3. Taxwim and Wibowo Octavian A. , "Simulasi dan Monitoring Sistem Interlock Mesin Berkas Elektron PTAPB BATAN dengan Perangkat Suara", Prosiding PPI PDIPTN, pp. 270-278, 2006

4. BATAN. (17 June 2017). Iradiator Gamma Merah Putih Siap Beroperasi. Available: http://www.batan.go.id/index.php/id/kedep utian/pendayagunaan-teknologinuklir/rekayasa-fasilitas-nuklir/3442iradiator-gamma-merah-putih-siapberoperasi

5. IAEA, "Radiation Safety of Gamma, Elektron and $X$ Ray Irradiation Facilities, Specific Safety Guide No. SSG-8": IAEA, 2010

6. Saminto and Santosa Budi, "Model Simulasi Sistem Interlock Mesin Berkas Elektron PTAPB-BATAN Berbasis LabVIEW". Prosiding PPI - PDIPTN, pp. $153-163,2006$ 
JURNAL FORUM NUKLIR (JFN) VOLUME 12, NOMOR 1, MEI 2018

Tabel.L1. Tabel logika hubungan antar sensor deteksi kebakaran

\begin{tabular}{|c|c|c|c|c|c|c|c|c|c|c|c|c|c|c|c|c|c|c|c|c|c|c|c|c|c|c|c|c|}
\hline \multicolumn{28}{|c|}{ Nama sensor } & \multirow{3}{*}{$\begin{array}{c}\text { Deteksi } \\
\text { kebakaran (DK) }\end{array}$} \\
\hline$K$ & $\kappa$ & $K$ & $K$ & $\kappa$ & K & $\kappa$ & $\boldsymbol{K}$ & $\kappa$ & $K$ & $K$ & $\kappa$ & $K$ & $K$ & $K$ & $K$ & $K$ & $K$ & $K$ & $K$ & $K$ & $\boldsymbol{K}$ & $K$ & $K$ & $\kappa$ & $K$ & $K$ & $K$ & \\
\hline 1 & 2 & 3 & 4 & 5 & 6 & 7 & 8 & 9 & 10 & 11 & 12 & 13 & 14 & 15 & 16 & 17 & 18 & 19 & 20 & 21 & 22 & 23 & 24 & 25 & 26 & 27 & 28 & \\
\hline 0 & $\mathrm{X}$ & $x$ & $x$ & $\mathrm{X}$ & $x$ & $x$ & $x$ & $x$ & $x$ & $x$ & $x$ & $x$ & $x$ & $x$ & $x$ & $x$ & $x$ & $x$ & $x$ & $x$ & $\mathrm{x}$ & $x$ & $x$ & $x$ & $x$ & $x$ & $\mathrm{X}$ & 0 \\
\hline$x$ & 0 & $x$ & $x$ & $x$ & $x$ & $x$ & $x$ & $x$ & $x$ & $x$ & $x$ & $x$ & $x$ & $x$ & $x$ & $x$ & $x$ & $x$ & $x$ & $x$ & $x$ & $x$ & $x$ & $x$ & $x$ & $x$ & $x$ & 0 \\
\hline$x$ & $x$ & 0 & $x$ & $x$ & $x$ & $x$ & $x$ & $x$ & $x$ & $x$ & $x$ & $x$ & $x$ & $x$ & $x$ & $x$ & $x$ & $x$ & $x$ & $x$ & $x$ & $x$ & $x$ & $x$ & $x$ & $x$ & $x$ & 0 \\
\hline$x$ & $x$ & $x$ & 0 & $x$ & $x$ & $x$ & $x$ & $x$ & $x$ & $x$ & $x$ & $x$ & $x$ & $x$ & $x$ & $x$ & $x$ & $x$ & $x$ & $x$ & $x$ & $x$ & $x$ & $x$ & $x$ & $x$ & $x$ & 0 \\
\hline$x$ & $x$ & $x$ & $x$ & 0 & $x$ & $x$ & $x$ & $x$ & $x$ & $x$ & $x$ & $x$ & $x$ & $x$ & $x$ & $x$ & $x$ & $x$ & $x$ & $x$ & $x$ & $x$ & $x$ & $x$ & $x$ & $x$ & $x$ & 0 \\
\hline$x$ & $x$ & $x$ & $x$ & $x$ & 0 & $x$ & $x$ & $x$ & $x$ & $x$ & $x$ & $x$ & $x$ & $x$ & $x$ & $x$ & $x$ & $x$ & $x$ & $x$ & $x$ & $x$ & $x$ & $x$ & $x$ & $x$ & $x$ & 0 \\
\hline$x$ & $x$ & $x$ & $x$ & $x$ & $x$ & 0 & $x$ & $x$ & $x$ & $x$ & $x$ & $x$ & $x$ & $x$ & $x$ & $x$ & $x$ & $x$ & $x$ & $x$ & $x$ & $x$ & $x$ & $x$ & $x$ & $x$ & $x$ & 0 \\
\hline$x$ & $x$ & $x$ & $x$ & $x$ & $x$ & $x$ & 0 & $x$ & $x$ & $x$ & $x$ & $x$ & $x$ & $x$ & $x$ & $x$ & $x$ & $x$ & $x$ & $x$ & $x$ & $x$ & $x$ & $x$ & $x$ & $x$ & $x$ & 0 \\
\hline$x$ & $x$ & $x$ & $x$ & $x$ & $x$ & $x$ & $x$ & 0 & $x$ & $x$ & $x$ & $x$ & $x$ & $x$ & $x$ & $x$ & $x$ & $x$ & $x$ & $x$ & $x$ & $x$ & $x$ & $x$ & $x$ & $x$ & $x$ & 0 \\
\hline$x$ & $x$ & $x$ & $x$ & $x$ & $x$ & $x$ & $x$ & $x$ & 0 & $x$ & $x$ & $x$ & $x$ & $x$ & $x$ & $x$ & $x$ & $x$ & $x$ & $x$ & $x$ & $x$ & $x$ & $x$ & $x$ & $x$ & $x$ & 0 \\
\hline$x$ & $x$ & $x$ & $x$ & $x$ & $x$ & $x$ & $x$ & $x$ & $x$ & 0 & $x$ & $x$ & $x$ & $x$ & $x$ & $x$ & $x$ & $x$ & $x$ & $x$ & $x$ & $x$ & $x$ & $x$ & $x$ & $x$ & $x$ & 0 \\
\hline$x$ & $x$ & $x$ & $x$ & $x$ & $x$ & $x$ & $x$ & $x$ & $x$ & $x$ & 0 & $x$ & $x$ & $x$ & $x$ & $x$ & $x$ & $x$ & $x$ & $x$ & $x$ & $x$ & $x$ & $x$ & $x$ & $x$ & $x$ & 0 \\
\hline$x$ & $x$ & $x$ & $x$ & $x$ & $x$ & $x$ & $x$ & $x$ & $x$ & $x$ & $x$ & 0 & $x$ & $x$ & $x$ & $x$ & $x$ & $x$ & $x$ & $x$ & $x$ & $x$ & $x$ & $x$ & $x$ & $x$ & $x$ & 0 \\
\hline$x$ & $x$ & $x$ & $x$ & $x$ & $x$ & $x$ & $x$ & $x$ & $x$ & $x$ & $x$ & $x$ & 0 & $x$ & $x$ & $x$ & $x$ & $x$ & $x$ & $x$ & $x$ & $x$ & $x$ & $x$ & $x$ & $x$ & $x$ & 0 \\
\hline$x$ & $x$ & $x$ & $x$ & $x$ & $x$ & $x$ & $x$ & $x$ & $x$ & $x$ & $x$ & $x$ & $x$ & 0 & $x$ & $x$ & $x$ & $x$ & $x$ & $x$ & $x$ & $x$ & $x$ & $x$ & $x$ & $x$ & $x$ & 0 \\
\hline$x$ & $x$ & $x$ & $x$ & $x$ & $x$ & $x$ & $x$ & $x$ & $x$ & $x$ & $x$ & $x$ & $x$ & $x$ & 0 & $x$ & $x$ & $x$ & $x$ & $x$ & $x$ & $x$ & $x$ & $x$ & $x$ & $x$ & $x$ & 0 \\
\hline$x$ & $x$ & $x$ & $x$ & $x$ & $x$ & $x$ & $x$ & $x$ & $x$ & $x$ & $x$ & $x$ & $x$ & $x$ & $x$ & 0 & $x$ & $x$ & $x$ & $x$ & $x$ & $x$ & $x$ & $x$ & $x$ & $x$ & $x$ & 0 \\
\hline$x$ & $x$ & $x$ & $x$ & $x$ & $x$ & $x$ & $x$ & $x$ & $x$ & $x$ & $x$ & $x$ & $x$ & $x$ & $x$ & $x$ & 0 & $x$ & $x$ & $x$ & $x$ & $x$ & $x$ & $x$ & $x$ & $x$ & $x$ & 0 \\
\hline$x$ & $x$ & $x$ & $x$ & $x$ & $x$ & $x$ & $x$ & $x$ & $x$ & $x$ & $x$ & $x$ & $x$ & $x$ & $x$ & $x$ & $x$ & 0 & $x$ & $x$ & $x$ & $x$ & $x$ & $x$ & $x$ & $x$ & $x$ & 0 \\
\hline$x$ & $x$ & $x$ & $x$ & $x$ & $x$ & $x$ & $x$ & $x$ & $x$ & $x$ & $x$ & $x$ & $x$ & $x$ & $x$ & $x$ & $x$ & $x$ & 0 & $x$ & $x$ & $x$ & $x$ & $x$ & $x$ & $x$ & $x$ & 0 \\
\hline$x$ & $x$ & $x$ & $x$ & $x$ & $x$ & $x$ & $x$ & $x$ & $x$ & $x$ & $x$ & $x$ & $x$ & $x$ & $x$ & $x$ & $x$ & $x$ & $x$ & 0 & $x$ & $x$ & $x$ & $x$ & $x$ & $x$ & $x$ & 0 \\
\hline$x$ & $x$ & $x$ & $x$ & $x$ & $x$ & $x$ & $x$ & $x$ & $x$ & $x$ & $x$ & $x$ & $x$ & $x$ & $x$ & $x$ & $x$ & $x$ & $x$ & $x$ & 0 & $x$ & $x$ & $x$ & $x$ & $x$ & $x$ & 0 \\
\hline$x$ & $x$ & $x$ & $x$ & $x$ & $x$ & $x$ & $x$ & $x$ & $x$ & $x$ & $x$ & $x$ & $x$ & $x$ & $x$ & $x$ & $x$ & $x$ & $x$ & $x$ & $x$ & 0 & $x$ & $x$ & $x$ & $x$ & $x$ & 0 \\
\hline$x$ & $x$ & $x$ & $x$ & $x$ & $x$ & $x$ & $x$ & $x$ & $x$ & $x$ & $x$ & $x$ & $x$ & $x$ & $x$ & $x$ & $x$ & $x$ & $x$ & $x$ & $x$ & $x$ & 0 & $x$ & $x$ & $x$ & $x$ & 0 \\
\hline$x$ & $x$ & $x$ & $x$ & $x$ & $x$ & $x$ & $x$ & $x$ & $x$ & $x$ & $x$ & $x$ & $x$ & $x$ & $x$ & $x$ & $x$ & $x$ & $x$ & $x$ & $x$ & $x$ & $x$ & 0 & $x$ & $x$ & $x$ & 0 \\
\hline$x$ & $x$ & $x$ & $x$ & $x$ & $x$ & $x$ & $x$ & $x$ & $x$ & $x$ & $x$ & $x$ & $x$ & $x$ & $x$ & $x$ & $x$ & $x$ & $x$ & $x$ & $x$ & $x$ & $x$ & $x$ & 0 & $x$ & $x$ & 0 \\
\hline$x$ & $x$ & $x$ & $x$ & $x$ & $x$ & $x$ & $x$ & $x$ & $x$ & $x$ & $x$ & $x$ & $x$ & $x$ & $x$ & $x$ & $x$ & $x$ & $x$ & $x$ & $x$ & $x$ & $x$ & $x$ & $x$ & 0 & $x$ & 0 \\
\hline$x$ & $x$ & $x$ & $x$ & $x$ & $x$ & $x$ & $x$ & $x$ & $x$ & $x$ & $x$ & $x$ & $x$ & $x$ & $x$ & $x$ & $x$ & $x$ & $x$ & $x$ & $x$ & $x$ & $x$ & $x$ & $x$ & $x$ & 0 & 0 \\
\hline 1 & 1 & 1 & 1 & 1 & 1 & 1 & 1 & 1 & 1 & 1 & 1 & 1 & 1 & 1 & 1 & 1 & 1 & 1 & 1 & 1 & 1 & 1 & 1 & 1 & 1 & 1 & 1 & 1 \\
\hline
\end{tabular}

